\title{
MINERAL RESOURCE POTENTIAL OF THE BIRDSEYE, NEPHI, AND SANTAQUIN ROADLESS AREAS,
} JUAB AND UTAH COUNTIES, UTAH

\section{SUMMARY REPORT}

\author{
By
}

Martin L. Sorensen

U.S. Geological Survey

and

\section{Stanley L. Korzeb and John T. Neubert}

U.S. Bureau of Mines

\section{STUDIES RELATED TO WILDERNESS}

Under the provisions of the Wilderness Act (Public Law 88-577, September 3, 1964) and related acts, the U.S. Geological Survey and the U.S. Bureau of Mines have been conducting mineral surveys of wilderness and primitive areas. Areas officially designated as "wilderness," "wild," or "canoe" when the act was passed were incorporated into the National Wilderness Preservation System, and some of them are presently being studied. The act provided that areas under consideration for wilderness designation should be studied for suitability for incorporation into the Wilderness System. The mineral surveys constitute one aspect of the suitability studies. The act directs that the results of such surveys are to be made available to the public and be submitted to the President and the Congress. This report discusses the results of a mineral survey of the Birdseye, Nephi, and Santaquin Roadless Areas, Uinta National Forest, Juab and Utah Counties, Utah. The Birdseye (4726), Nephi (4729), and Santaquin (4720) Roadless Areas were classified as further planning areas during the Second Roadless Area Review and Evaluation (RARE II) by the U.S. Forest Service, January 1979.

\section{SUMMARY}

The U.S. Geological Survey and the U.S. Bureau of Mines have conducted a survey to determine the mineral resource potential of the Birdseye, Nephi, and Santaquin Roadless Areas, Juab and Utah Counties, Utah. The results of this survey indicate several areas with mineral resource potential. A high potential for a small lead-zinc-silver deposit is recognized in the Santaquin Roadless Area at the Eva (Privateer) mine. A moderate potential for other lead-zine-silver deposits exists at the Eva mine and elsewhere in the study area in Cambrian and Mississippian carbonate rocks. A high potential for gypsum is recognized at a deposit on three patented claims in the southwest corner of the Nephi Roadless Area. The potential for other gypsum deposits elsewhere in the study area in tracts underlain by the Arapien Shale is moderate to low. There is a high potential for limestone and dolomite for use in cement and as smelter flux in the Nephi and Santaquin Roadless Areas. The potential for uranium is low throughout the study area. The potential for oil and gas deposits is probably moderate to low throughout the study area. There are no indications of coal or geothermal resources in the study area.

\section{INTRODUCTION}

Field investigations of the study area during 1981 and 1982 consisted of a survey of mines, prospects, and mineralized zones by the U.S. Bureau of Mines and geologic mapping and geochemical sampling by the U.S. Geological Survey. The U.S. Bureau of Mines searched the records of Juab and Utah Counties for locations of unpatented mining claims and U.S. Bureau of Land Management records for patented and unpatented claims and federal mineral leases. This report summarizes the findings of these investigations and includes a map showing mineral resource potential in the roadless areas.

\section{LOCATION, SIZE, AND GEOGRAPHIC SETTING}

The Birdseye, Nephi, and Santaquin Roadless Areas are in the southern part of the Wasatch Mountains in central Utah (fig. 1) where the Wasatch Mountains form the westernmost part of the Rocky Mountains and are separated from the Basin and Range province by the Wasatch fault. The roadless areas are located a few miles south to east of Santaquin and 55 mi south of Salt Lake City, where they occupy approximately 13,220 (Birdseye), 24,000 (Nephi), and 12,880 (Santaquin) acres respectively in the Uinta National Forest. The roadless areas are roughly bounded by Interstate Highway 15 on the west, U.S. Highway 89 on the east (just off map on fig. 1), and Utah State Highway 132 on the south; access to the areas is provided by the paved Nebo Loop and Santaquin
Canyon Roads and by an unpaved jeep trail in Pole Canyon. The study area is bordered on the west by the northtrending Wasatch fault. Differential movement along this fault has produced a rugged topography; elevations in the study area range from approximately $5,300 \mathrm{ft}$ near Nephi to $11,887 \mathrm{ft}$ at Mount Nebo.

\section{GEOLOGIC SETTING}

\section{Stratigraphy}

The stratigraphic descriptions used in this report are based on Hintze (1962), with modifications from Black (1965), Brady (1965), and H. Pietropaoli and M. Sorensen (unpub. data). All reported unit thicknesses are approximate.

The Wasatch Mountains in the area of this report are underlain by approximately $26,000 \mathrm{ft}$ of sedimentary rocks that range in age from Proterozoic to Tertiary and by scattered outcrops of Tertiary volcanic rocks.

The oldest rocks in the area are Proterozoic in age. They comprise $900 \mathrm{ft}$ of tan-weathering quartzite and dark shale where exposed along the west border of the Santaquin Roadless Area and are unconformably overlain by Paleozoic sedimentary rocks. The base of the Paleozoic section is composed of approximately $900 \mathrm{ft}$ of Cambrian quartzite and is overlain by $2,000 \mathrm{ft}$ of Cambrian shale, limestone, and dolomite. These rocks are unconformably overlain by discontinuous outcrops of Devonian dolomite and quartzite and by 
2,300 $\mathrm{ft}$ of Mississippian limestone, dolomite, quartzite, and shale.

A Mississippian and Pennsylvanian shale separates these rocks from the rest of the Paleozoic section, which consists of $11,000 \mathrm{ft}$ of interbedded limestone and quartzite of Pennsylvanian and Permian age, overlain by $1,300 \mathrm{ft}$ of limestone, sandstone, dolomite, and shale of Permian age.

Mesozoic strata in the study area consist of $3,000 \mathrm{ft}$ of Triassic shale and limestone overlain by a $1,500 \mathrm{ft}$-thick sandstone formation of Triassic(?) and Jurassic(?) age that is overlain, in turn, by $2,700 \mathrm{ft}$ of sandstone, siltstone, and mudstone of Jurassic age. Shale in the upper part of the Mesozoic section east of Nephi commonly includes gypsumand evaporite-bearing beds. The uppermost Mesozoic and lower Tertiary formations exposed in the study area include shale, sandstone, and conglomerate. The uppermost conglomerates are overlain, in places, by discontinuous outcrops of Tertiary freshwater limestone and (or) andesitic volcanic rocks. Quaternary surficial deposits within the study area include alluvial, fan, glacial, landslide, and talus deposits.

\section{Structure}

The surface geology throughout most of the three roadless areas is generally uncomplicated. Rocks in the Birdseye and Santaquin Roadless Areas are homoclinal and dip east to southeast at moderate angles, but steepen southward and are near vertical to overturned throughout the southern part of the Nephi Roadless Area.

Eastward-directed thrust faulting in the Sevier orogenic belt (Armstrong, 1968) during middle and late Mesozoic time resulted in the emplacement of large thrustbounded blocks throughout much of eastern Nevada and western Utah. The Birdseye, Nephi, and Santaquin Roadless Areas occupy part of the Charleston-Nebo thrust block (Roberts and others, 1965, p. 1946) and are underlain, with the exception of a few square miles of the Nephi Roadless Area, by the Nebo thrust fault. The trace of the Nebo thrust is exposed within the Nephi Roadless Area a few miles northeast of Nephi where it has emplaced the upper Paleozoic Oquirrh Formation above Mesozoic Arapien Shale and Nugget Sandstone (Black, 1965). A thrust fault exposed in Santaquin Canyon has been identified as a northern extension of the Nebo thrust (Brady, 1965, p. 40), but it seems more likely that it is an imbricate thrust rising from an unexposed extension of the Nebo thrust. A thrust fault exposed in the northwest corner of the Birdseye Roadless Area probably bears a similar relationship to the Nebo thrust.

\section{MINING ACTIVITY}

Although 17 patented claims and about 240 unpatented claims are located in or within $1 \mathrm{mi}$ of the roadless areas, there is no current mining or exploration activity in or near the Birdseye, Nephi, and Santaguin Roadless Areas. Prospecting for uranium and drilling for cement-grade limestone took place in the southwest part of the Nephi Roadless Area between 1970 and 1976 .

\section{GEOLOGY AND GEOCHEMISTRY}

\section{GEOLOGY}

Several geologic environments with potential for mineral resource occurrence were delineated during the present study.

\section{Arapien shale}

The Jurassic Arapien Shale underlies a large area south of the Nephi Roadless Area. The Arapien has long been known to contain gypsum, anhydrite, halite, and other evaporite minerals (Stone and Lupton, 1920, p. 265). Gypsum was mined from deposits in the Arapien Shale east of Nephi from 1882 to approximately 1925, when more accessible deposits were developed in outcrops of the Arapien near Levan, Utah, $22 \mathrm{mi}$ south of Nephi. The Arapien Shale is exposed over approximately $1 \mathrm{mi}^{2}$ and may be present in the subsurface beneath the Nebo thrust in the southern part of the Nephi Roadless Area. Wherever present, the Arapien Shale is a potential host for gypsum and evaporite minerals.

\section{Paleozoic rocks}

Small lead-zine-silver deposits occur in Paleozoic limestone and dolomite in the Mount Nebo and Santaquin mining districts. Most deposits are bedded replacements and fissure fillings in Cambrian and Mississippian dolomite and limestone and appear to have been localized by intersecting faults (Phillips, 1940). Limestone and dolomite beds free from clay impurities and possessing a granular texture are those most likely to contain ore bodies (Loughlin, 1920, p. 330 ). Most of the larger ore bodies occur near the top of the Mississippian Deseret Limestone in a partially dolomitized coarsely crystalline crinoidal limestone locally known as the Eva dolomite (Phillips, 1940, p. 60, 62, 65), whose coarsely crystalline texture makes it susceptible to replacement by mineralizing solutions. Carbonate rocks with similar textures are found in beds of Cambrian and Mississippian age that crop out west of the Deseret Limestone and contain smaller mineral deposits. Cambrian carbonate rocks in brecciated beds favorable for mineralization are also exposed in the northwest part of the Birdseye Roadless Area.

Dikes and sills are spatially associated with mineralized zones in the western part of the Nephi and Santaquin Roadless Areas. Lamprophyre dikes injected through fissures were followed by later mineralizing fluids. In areas with few fissures, large mineral deposits developed. In areas where fissures are numerous, the solutions spread and produced multiple small mineral deposits (Phillips, 1940, p. 76).

All of the mineral deposits investigated in the roadless areas show evidence of being highly altered by ground water. Most of the lead and zine minerals in the ore bodies are secondary. The leaching process probably also removed most of the silver from the ores (Phillips, 1940, p. 65).

Copper prospects have been located in Proterozoic gneiss west of the Santaquin Roadless Area, Cambrian quartzite in both the Nephi and Santaquin Roadless Areas, and Paleozoic carbonate rocks in the Nephi Roadless Area. Production is noted for only one deposit, located outside of the roadless areas, and is described by Bullock $(1962$, p. 90$)$ as extremely minor.

\section{Rocks beneath the Charleston-Nebo thrust fault}

Exposures northeast of Nephi show that, at least locally, the lower plate of the Nebo thrust includes rocks assigned to the Nugget Sandstone, an important petroleum reservoir rock in the overthrust belt of northeastern Utah. The Nugget Sandstone or other potential reservoir rocks may be present in the subsurface beneath the Charleston-Nebo thrust block, but this cannot be determined without an extensive program of geophysical exploration and exploratory drilling.

\section{GEOCHEMISTRY}

A geochemical sampling program was undertaken as an aid in the mineral resource evaluation of the Birdseye, Nephi, and Santaquin Roadless Areas. During this study, a total of 27 altered or mineralized rock, 173 stream-sediment, and 147 stream-sediment-concentrate samples were analyzed for 31 elements by semiquantitative emission spectrographic analysis methods. Results of the analyses are reported by Sorensen and others (1983). A hydrogeochemical survey of the roadless areas was conducted during July 1981. Thirtynine water samples were collected from springs and streams and analyzed for 12 elements.

Many of the rocks analyzed contained visible, galena and were collected from mine or prospect pit dumps along the west edge of the Nephi and Santaquin Roadless Areas. Seven samples contain high values for lead $(>20,000 \mathrm{ppm}$, parts per million) and (or) zine $(>10,000 \mathrm{ppm})$. Moderately high values for silver $(\leq 300 \mathrm{ppm})$ occur in some of the samples with high lead-zinc content, and high values for cadmium ( $>500 \mathrm{ppm}$ ) 
occur in most of the zinc-rich samples.

Analysis of stream sediments indicates three areas with locally high values for several elements. Samples collected from the northwest corner of Birdseye Roadless Area, northwest corner of Santaquin Roadless Area, and from the west edge of. Nephi and Santaquin Roadless Areas contain slightly anomalous amounts of copper $(>50 \mathrm{ppm})$, lead $(\geq 500$ $\mathrm{ppm})$, silver $(\geq 1 \mathrm{ppm})$, and zine $(\geq 500 \mathrm{ppm})$. Panned concentrates of stream sediments show a similar pattern of high values for the same elements. The stream sediments and sediment concentrates containing these high values were all collected in areas that contain numerous prospect pits and small mines and apparently reflect local low-grade mineralization.

Analyses of the 39 water samples from springs and streams in the roadless areas did not disclose any unusual concentration of elements (John B. McHugh, U.S. Geological Survey, oral commun., 1983).

\section{MINING DISTRICTS AND MINERALIZED AREAS}

The U.S. Bureau of Mines studied the mines and prospects in and near the roadless areas. Samples were collected in mineralized or altered areas and at mine dumps. All samples were analyzed for gold and silver by fire-assay methods, and most were analyzed for 40 elements by semiquantitative spectrographic methods. Other methods provided analyses for specific elements. U.S. Bureau of Mines sample descriptions and assay data are available for public inspection at the U.S. Bureau of Mines in Denver 1 .

The Birdseye and northeast half of the Santaquin Roadless Areas are in the Santaquin mining district. The Santaquin district was organized in 1871 (Heikes, 1920, p. 148). Production from 1910 to 1917 was reported to be $208 \mathrm{lb}$ of copper, 206,522 lb of lead and 3,499 oz of silver (Bullock, 1962 , p. 90). All of the Nephi and the southwest half of the Santaquin Roadless Areas are in the Mount Nebo mining district. The district was organized in 1870 (Heikes, 1920, p. 147). Production from 1870 to 1917 was reported to be $15.29 \mathrm{oz}$ of gold, $37,226 \mathrm{oz}$ of silver, $1,526 \mathrm{lb}$ of copper, $1,932,683 \mathrm{lb}$ of lead, and 788,679 lb of zine (Heikes, 1920, p. 334). There has not been any recorded production since 1917. The total production from deposits in the Santaquin and Mount Nebo mining districts is modest and probably less than $\$ 500,000$ from 1870 to date (Bullock, 1962 , p. 88,90 )

\section{LEAD-ZINC-SILVER DEPOSITS}

Lead-zine-silver ore has been produced from mines in or near the Birdseye, Nephi, and Santaquin Roadless Areas. Production has been from mines near Mendenhall Creek, Pole Canyon, and the head of North Canyon in the Santaquin Roadless Area and the mouth of Bear Canyon in the Nephi Roadless Area (fig. 1). Descriptions of selected mines and prospects most typical of the minor mineral occurrences are given below and are followed by descriptions of the more important workings.

\section{SELECTED PROSPECTS}

The Eldorado prospect is a replacement-type deposit in brecciated Cambrian limestone in the northwest part of the Birdseye Roadless Area (fig. 2). Assays of 13 percent zinc, 5 percent lead, and $1.4 \mathrm{oz}$ per ton silver were reported in a mineral examination by the U.S. Forest Service (Dow, 1959). At the time of the Forest Service examination, the adits were accessible and the deposit could be sampled. Samples taken by the U.S. Bureau of Mines were collected from the dumps and adit portals and showed values of 0.05 percent lead and 0.10 percent zinc.

The Castle, Blue Eagle, and Silver Buck prospects are within and adjacent to the northern boundary of the Santaquin Roadless Area (fig. 2). Mineralization occurs as limonite- and cerussite-filled fractures in brecciated Mississippian and Pennsylvanian carbonate rocks.

The Santaquin Chief, Santaquin King, Deanna, and Big Nebo mines are located in Mendenhall Canyon within and adjacent to the western boundary of the Santaquin Roadless Area (fig. 2). The mines are developed in brecciated Cambrian and Mississippian carbonate rocks. The deposits are fracture fillings and replacements of host rock by leadand zinc-carbonate minerals.

\section{EVA AND HIGHLAND MINES}

The Eva mine area lies within and adjacent to the Santaquin Roadless Area; the roadless area boundary appears to extend through the workings (fig. 2). During 1912-13 a total of 809 tons of ore was produced and averaged 38 percent lead, 19.2 percent zinc, and 15.9 oz per ton silver. Total production from this mine is 10,000 tons (Defense Minerals Agency Docket 234, 1951).

Nearly all production has come from an informal unit of the Deseret Limestone, the Eva dolomite (Phillips, 1940), where mineralized layers separated by unmineralized layers follow bedding. The ore consists of coarsely to finely crystalline galena, lead-carbonate minerals, and secondary zine minerals (Phillips, 1940, p. 63). Gangue minerals are limonite, calcite, dolomite, and quartz.

The Eva mine has about $470 \mathrm{ft}$ of inclined adit, $500 \mathrm{ft}$ of horizontal drifts, and numerous complex stopes. The highest assay values from the Eva mine are $20.1 \mathrm{oz}$ per ton silver, 7.85 percent lead, and 44.5 percent zinc. Forty-six chip samples from the Eva mine have average assay values of $3.6 \mathrm{oz}$ per ton silver, 2.83 percent lead, and 1.97 percent zinc. On the basis of the geology and sample data, there appears to be approximately 1,000 tons of material of this average grade left in the Eva mine. Drilling or underground development is required to confirm the estimated tonnage and grade of the remaining ore deposit.

The Highland mines are $3,000 \mathrm{ft}$ north of the Eva mine and are outside of, but immediately adjacent to, the Santaquin Roadless Area (fig. 2). These mines are in a fault-bounded spur of Mississippian limestone. Much of the mineral deposit has been removed by erosion (Phillips, 1940, p. 60). Most samples contain less than 0.2 oz per ton silver, less than 0.5 percent lead, and less than 0.5 percent zinc. The highest values from the Highland mines are $7.2 \mathrm{oz}$ per ton silver, 4.70 percent lead, and 19 percent zinc.

\section{BEAR CANYON AREA}

There are numerous mines and prospects along the west boundary of the Nephi Roadless Area near Bear Canyon (Stanley Korzeb, unpub data, 1983). The most important of these workings are the Syndicate tunnel, Blackett tunnel, Burriston mine, and Eureka mine. Only the Eureka is within the roadless area. Production figures for these mines are unknown. Bullock $(1962$, p. 89) reports that peak production was reached in 1907 and the properties abandoned in 1929 . Further development was done in the 1950's by the Eureka Leasing and Mining Company and the Temple Mountain Uranium Company. Scattered amounts of mineralized rock remain in these workings.

Mineral deposits in the Bear Canyon area occur as replacement bodies and fissure fillings in the Deseret Limestone. The ore minerals are galena, cerussite, hydrozincite, and smithsonite; gangue minerals are limonite and calcite. Most samples from the Bear Canyon vicinity assayed less than $0.2 \mathrm{oz}$ per ton silver, less than 0.5 percent lead, and less than 0.5 percent zinc, although values up to $8.3 \mathrm{oz}$ per ton silver, 7.45 percent lead, and 19.5 percent zinc were determined for some samples. 


\section{URANIUM}

Uranium mineralization is present in a series of 10 pits on a block of lode claims in the southwest corner of the Nephi Roadless Area (fig. 2). Mineralization consisting of tyuyamunite (hydrated calcium uranyl vanadate) is confined to a bed of oolitic limestone at the base of the Arapien Shale. Oxidation of the original replacement deposit caused the primary uranium and vanadium minerals to break down and combine to form tyuyamunite. Tyuyamunite is insoluble, so a deposit formed through this process will retain the shape and grade of the original deposit (Nash and others, 1981). All workings are slumped and only scattered surface showings could be examined during the Bureau of Mines investigation. Four samples were assayed; the best chip sample contained 0.004 percent $\mathrm{U}_{3} \mathrm{O}_{8}$ and 0.05 percent vanadium.

In 1970, Cerro Corporation drilled 12 inclined holes $300 \mathrm{ft}$ from the known mineralized areas. In 1976, Monroc drilled 8 inclined holes, 200 and $100 \mathrm{ft}$ from the known mineralized areas. Results of the 1970 drilling and a geologic evaluation are given by Evans (1978). The purpose of the holes was to penetrate the oolitic limestone bed downdip to determine the extent and grade of mineralization. Four of Cerro's 12 holes contained no uranium or vanadium. Uranium content in the remaining holes ranged from 0.012 to 0.662 percent $\mathrm{U}_{3} \mathrm{O}_{8}$ and averaged 0.063 percent. Vanadium ranged from 0.013 to 0.5 percent $\mathrm{V}_{2} \mathrm{O}_{5}$ and averaged 0.104 percent. Mineralized intercepts ranged from 2 to $6 \mathrm{ft}$.

\section{LIMESTONE AND DOLOMITE}

Monroc Inc. drilled near Gardner Creek (fig. 1) in the southwest portion of the Nephi Roadless Area for cementgrade limestone in 1976 (Stanley Korzeb, unpub. data, 1983). According to Allen Flandro (oral commun., 1981), Monroc's agent on the investigation, limestone identified as Jurassic Twin Creek Limestone (included here with the Arapien Shale) showed good potential for use in cement. Monroc later found an area elsewhere that was more practical for the location of a cement plant and abandoned the Gardner Creek site (fig. 1).

Limestone and dolomite are industrial minerals that are used as fluxes in smelter operations. Rocks older than Humbug Formation (Upper Mississippian) and younger than Ophir Formation (Middle Cambrian) are mostly limestone and dolomite and underlie an area of approximately $9 \mathrm{mi}^{2}$ south of Santaquin Canyon.

\section{GYPSUM}

There are two known gypsum occurrences near the southwest boundary of the Nephi Roadless Area. Rowleys mine, located less than a mile outside the southwest boundary of the roadless area, is in the largest deposit. Just inside the roadless area boundary, a smaller deposit is located on three patented claims, the Little Doctor and the McFarlane 1 and 2 (fig. 2). The gypsum deposits occur as lenses in the Arapien Shale (Withington, 1964).

The deposit at Rowleys mine is believed to have been worked out by U.S. Gypsum; any remaining resources are unknown. The Little Doctor and McFarlane 1 and 2 patented claims include a lens that, based on surface exposures, is estimated to contain about 270,000 tons of 80 percent pure gypsum.

\section{OIL AND GAS}

Oil and gas leases and lease applications completely cover all three roadless areas. Current interest has been generated by the possibility of organic-rich sedimentary rocks, potential source rocks for petroleum (Ritzma, 1981) underlying the roadless areas.

Four oil companies, Amoco, Gulf, Exxon, and Quasar, ran seismic surveys through and near the three roadless areas in the summer of 1981, but the results of these surveys are unavailable.

\section{ASSESSMENT OF MINERAL RESOURCE POTENTIAL}

The mineral resource potential of the roadless areas is classified as high, moderate, or low, on the basis of geologic and geochemical investigations conducted for this study and on the history of mining and mineral exploration in the area. A high potential exists in an area where all or nearly all conditions for a geologic environment favorable for ore deposits are met. Such areas may include known mining districts and other areas where geologic, geochemical, geophysical, and other data demonstrate a high probability for the presence of mineralized rock. A moderate potential exists where a geologic environment favorable for ore deposits has been identified or may reasonably be inferred but where the evidence for mineralization is less definite or has not yet been found. Areas lacking either a high or moderate mineral resource potential are considered to have very little probability for mineral resources and are classified as having a low mineral resource potential.

\section{LEAD-ZINC-SILVER}

A high potential for a small lead-zinc-silver deposit is recognized at the Eva mine, where approximately 1,000 tons of ore remain from earlier mining activities. A moderate potential for other lead-zinc-silver deposits exists at the Eva mine and elsewhere in the Birdseye, Nephi, and Santaquin Roadless Areas. Mineralization in the Nephi and Santaquin Roadless Areas is concentrated in a zone underlain by Cambrian and Mississippian limestones and dolomites. $\mathrm{A}$ lead-zinc-silver deposit in the Birdseye Roadless Area is in the same stratigraphic setting. Rock samples collected from dumps at small mines and prospect pits contain moderate amounts of lead, zinc, and silver. Sediment samples collected from nearby drainages also contain these metals. Studies of known deposits in the mineralized areas suggest that any newly discovered deposits will be small, may be localized by faulting or intense folding, and may be spatially associated with lamprophyre dikes or sills. Although the upper part of the Deseret Limestone is the most favorable host rock, mineralization may occur in any of the Middle Cambrian through Upper Mississippian limestones or dolomites.

\section{URANIUM}

The mineral resource potential for uranium is low. The only known occurrence in the study area is in the southwest corner of the Nephi Roadless Area. Drilling and sample data reveal that mineralization is generally low grade and confined to a narrow zone. Due to the insolubility of the ore mineral, it is unlikely that enriched deposits will occur downdip from the mineralized occurrence.

\section{LIMESTONE AND DOLOMITE}

A high potential for cement-grade limestone is recognized near Gardner Creek in the southwest corner of the Nephi Roadless Area. This evaluation is based on drilling data and chemical analyses provided by Monroc, Inc., who conducted a survey for cement-grade limestone near Gardner Creek in 1976.

There is high potential in the study area for limestone and dolomite for use as smelter flux. Rocks mostly of this composition underlie $9 \mathrm{mi}^{2}$ south of Santaquin Canyon in the Nephi and Santaquin Roadless Areas. An extensive program of sampling and testing is necessary to determine the purity of the rocks and, hence, the value of the resource. The value of these rocks as industrial minerals is diminished by their inaccessibility and by the presence of limestone and dolomite quarries already in operation at West Mountain, approximately $4 \mathrm{mi}$ northwest of Santaquin Canyon.

\section{GYPSUM}

High potential for gypsum is recognized at three patented claims at the southwest corner of the Nephi Roadless Area, where approximately 270000 tons of 80 percent gypsum are estimated to be present. The Arapien 
Shale, in which the gypsum occurs, underlies less than $1 \mathrm{mi}^{2}$ of the roadless area and the potential for undiscovered gypsum deposits within this part of the study area is moderate to high.

\section{OIL AND GAS}

Recent leasing and exploration activities suggest the possibility of oil and gas deposits in or near the roadless areas, but the surface geology within the roadless areas does not indicate the presence of such deposits. The oil and gas potential of the three roadless areas cannot be accurately determined without the knowledge derived from a subsurface exploration program. Drilling has not taken place in or near the roadless areas and it is assumed that the potential for oil and gas is moderate to low.

\section{OTHER RESOURCES}

There are no indications of coal or geothermal resources in the study area.

\section{REFERENCES}

Armstrong, R. L., 1968, Sevier orogenic belt in Nevada and Utah: Geological Society of America Bulletin, v. 79, p. 429-458.

Black, B. A., 1965, Nebo overthrust, southern Wasatch Mountains, Utah: Brigham Young University Geology Studies, v. 12, p. 55-90.

Brady, M. J., 1965, Thrusting in the southern Wasatch Mountains, Utah: Brigham Young University Geology Studies, v. 12 , p. $3-54$.

Bullock, K. C., 1962, Economic geology of north-central Utah, in Hintze, L. F., ed., Geology of the southern Wasatch Mountains and vicinity, Utah: Brigham Young University Geology Studies, v. 9, pt. 1, p. 85-94.

Cluff, L. S., Brogan, G. E., and Glass, C. E., 1973, Wasatch Fault-Southern Portion, Earthquake fault investigation and evaluation: Woodward-Lundgren and Associates, Oakland, California, report for the Utah Geological and Mineralogical Survey.

Defense Minerals Agency Docket 234, 1951, Privateer Mining Company, Mount Nebo mining district, Provo, Utah: U.S. Bureau of Mines Records, Denver, Colorado, 13 p.
Dow, V. T., 1959, Eldorado Nos. 1 and 2 mining claims, in Unpublished report of mineral examination: Provo, Utah, U.S. Forest Service, Uinta National Forest Headquarters, p. 1-3.

Evans, D. L., 1978, Steele uranium property, Mount Nebo area, Juab County, Utah: Unpublished report by consulting geologist, Reno, Nevada, p. 4-13.

Heikes, V. C., 1920, History and production, in Butler, B. S., Loughlin, G. F., Heikes, V. C. and others, The ore deposits of Utah: U.S. Geological Survey Professional Paper 111, p. 116-149, 333-335.

Hintze, L. F., ed., 1962, Geology of the southern Wasatch Mountains and vicinity, Utah: Brigham Young University Geology Studies, v. 9, pt. 1, p. 1-104.

Loughlin, G. F., 1920, Santaquin and Mount Nebo region, in Butler, B. S., Loughlin, G. F., Heikes, V. C. and others, The ore deposits of Utah: U.S. Geological Survey Professional Paper III, p. 322-333.

Nash, J. T., Granger, H. C., and Adams, S. S., 1981, Geology and concepts of important types of uranium deposits: Economic Geology Seventy-fifth Anniversary Volume 1905-80, Economic Geology Publishing Company, El Paso, Texas, p. 103-104.

Phillips, K. A., 1940, The mining geology of the Mount Nebo district, Utah: Ames, lowa, lowa State College, M.S. thesis, $76 \mathrm{p}$.

Ritzma, H. R., 1981, Oiling the "Hingeline": Utah Geological and Mineral Survey, Survey Notes, v. 15, no. 4, p. 4.

Roberts, R. J., Crittenden, M. D. Jr., Tooker, E. W., Morris, H. T., Hose, R. K., and Cheney, T. M., 1965, Pennsylvanian and Permian basins in northwestern Utah, northeastern Nevada, and south-central Idaho: Bulletin of the American Association of Petroleum Geologists, v. 49, p. 1926-1956.

Sorensen, M. L., Pietropaoli, Henry, and Haley, S. M., 1983, Geochemical analyses of rock and stream-sediment samples from Birdseye, Nephi, and Sataquin Roadless Areas, Juab and Utah Counties, Utah: U.S. Geological Survey Open-File Report 83-175, 1 map, scale $1: 62,500$.

Stone, R. W., and Lupton, C. T., 1920, Gypsum deposits, Utah, in Stone, R. W., and others, Gypsum deposits of the United States: U.S. Geological Survey Bulletin 697, p. 261-265.

Withington, C. F., 1964, Gypsum and anhydrite, in Mineral and water resources of Utah: Utah Geological and Mineral Survey, Bulletin 73, p. 182-183. 


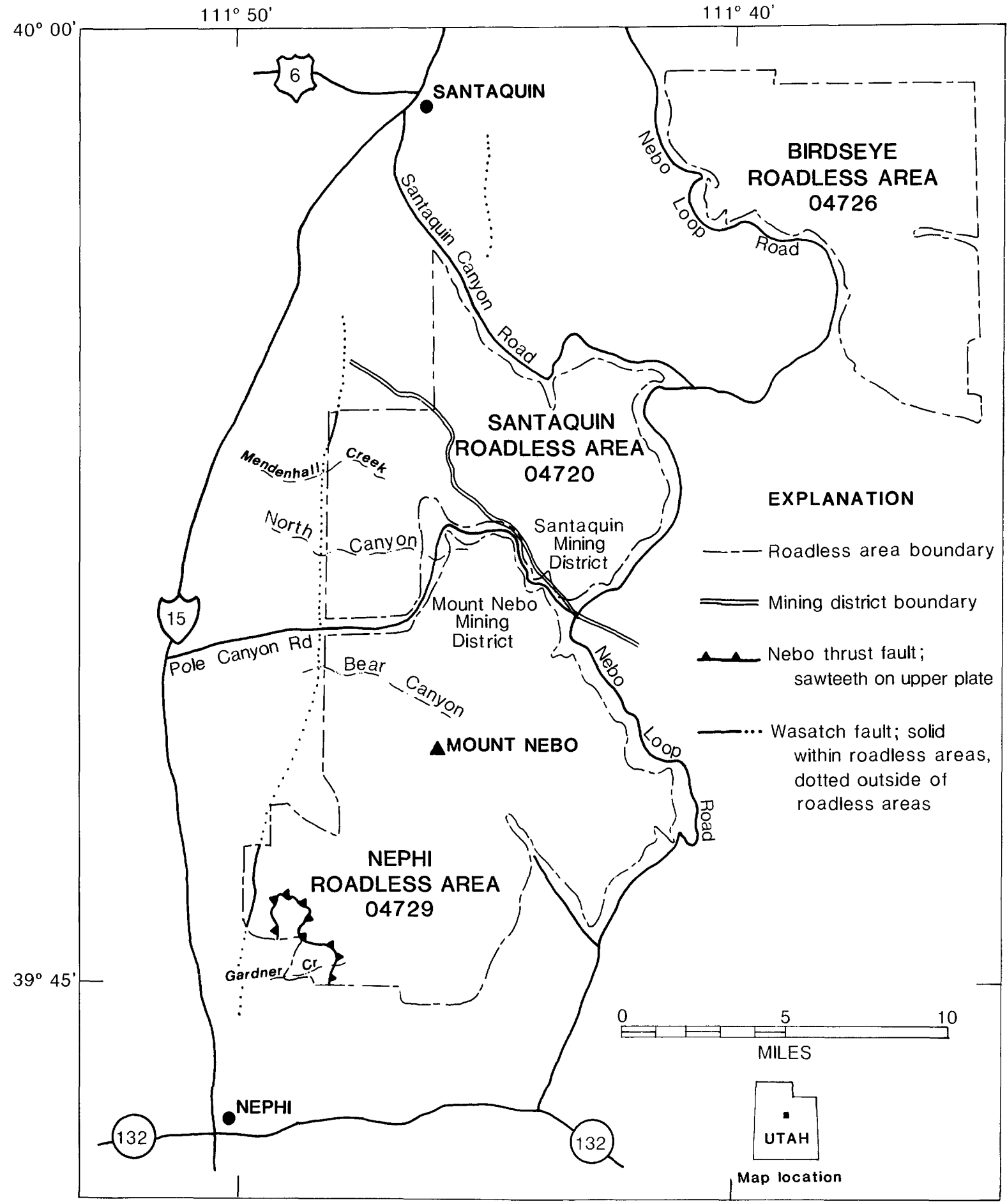

Figure 1.--Index map showing location of Birdseye (04726), Nephi (04729), and Santaquin (04720) Roadless Areas, Juab and Utah Counties, Utah. 


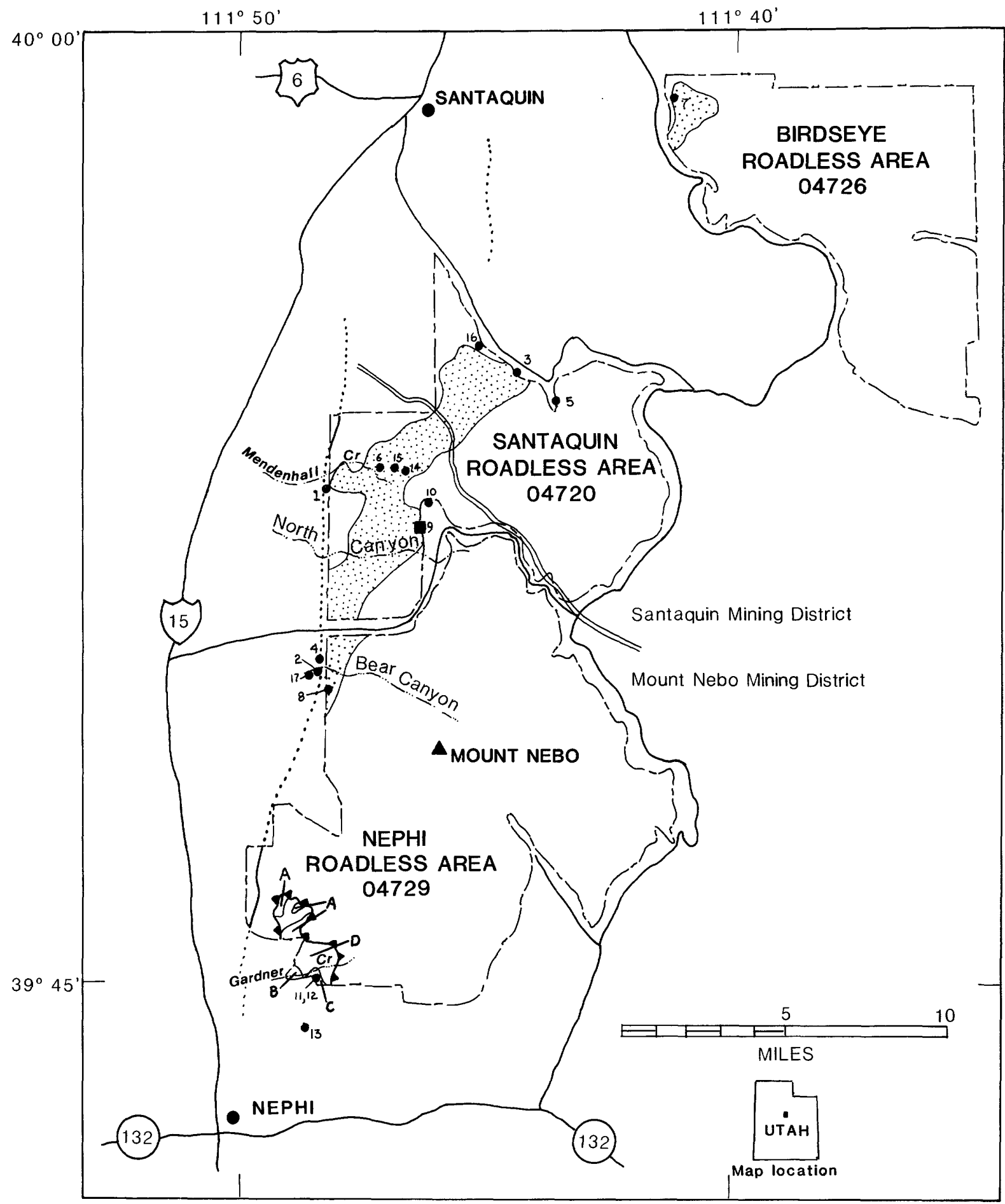

Figure 2.--Mineral resource potential of the Birdseye (04726), Nephi (04729), and Santaqu in Roadless Areas, Juab and Utah Counties, Utah. See following page for explanation of symbols 


\section{EXPLANATION FOR FIGURE 2}

Locality (Eva mine) with high potential for $\operatorname{small}(1,000$ ton) deposit of lead-zinc-silver ore

a

Area with moderate potential for lead-zinc-silver deposits and high potential for smelter-grade limestone and dolomite

A

B

C

D

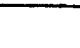

$+7$

- Mine or prospect

Selected mines and prospects

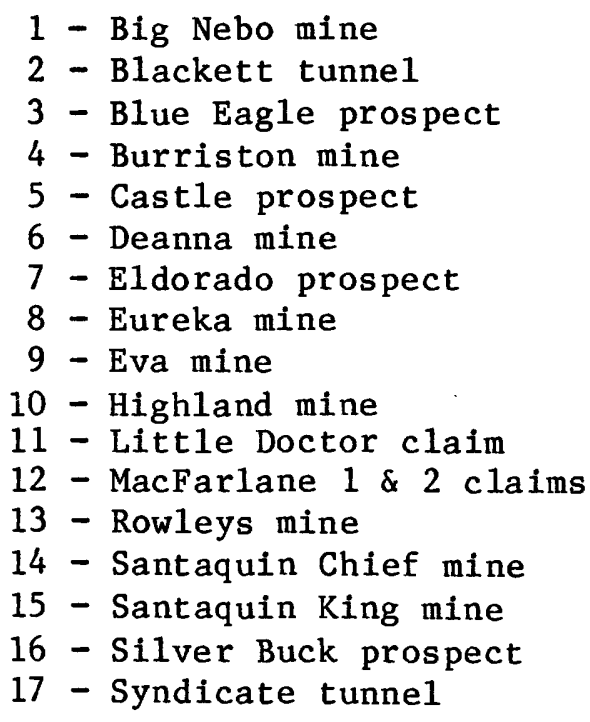

See figure 1 for explanation of other symbols 